\title{
Microfacies Analysis and Diagenetic Settings of Upper Cretaceous Shallow Water Carbonates from the Borizana Section (Kruja Zone, Albania)
}

\author{
M.Sc. Ana Qorri \\ Department of Earth Sciences, Faculty of Geology and Mining, Tirana, Albania \\ Email: ana.qorri@fgjm.edu.al
}

\section{Doi:10.5901/ajis.2015.v4n2p95}

Abstract

This paper deals with the preliminary results of a detailed study based on the microfacies analysis and diagenetic settings of the Upper Cretaceous shallow water carbonate deposits from Borizana section, Kruja zone, Albania. In the Makareshi structure, the Upper Cretaceous deposits, in the mainly consists of limestones, dolomitic limestones and different levels of dolomite intercalations. The study was carried out after a systematic sampling of a total of 230 rock samples and then by studying selected thin sections from individual beds and from different parts of the same bed. 250 thin sections were studied from a $1000 \mathrm{~m}$ thick section in order to analyse its sedimentology, microfacies assemblages and diagenetic featuress. Different types of microfacies mainly represented by laminated, peloidal and bioclastic grainstones along with presence of dolomitized microfacies at some levels were determined. Also different types of cement and diagenetic features such as compaction, dolomitization and neomorphism were also observed in Borizana section. All these microfacies associations and their diagenetic features indicate that this formation has been deposited in a restricted platform interior facies belt (FZ8, FZ9).

Keywords: Upper Cretaceous, carbonates, microfacies, diagenesis.

\section{Introduction}

The Kruja Zone is located in the central part of Albania and represents a carbonate platform that extends toward south, in Greece with Gabrovo Zone (Papa, 1970; Peza, 1973, 1975, 1977, 1982; I.S.P.GJ. - I.GJ.N. 1983; Meço and Aliaj, 2000; Robertson and Shallo, 2000; Heba and Prichonnet, 2006, 2008). The Borizana section is found in the Makareshi structure (Fig. 1a), where the Santonian, Campanian and Maastrichtian deposits are represented by limestones, dolomitic limestones and thick layered dolomites (Fig. 1b) containing debris of different organisms such as Rhapydionina liburnica, Accordiella conica, Hedbergella sp., Pithonella ovalis, Thaumatoporella parvovesiculifera, Aeolisaccus kotori, Lepidorbitoides sp, Orbitoides sp., etc. There are also rudists belonging to genra such as Radiolites and Hippurites, etc. Above the Upper Cretaceous deposits, those belonging to Danian - Thanetian occur in bauxite pockets, The Eocene deposits consist of thin-bedded limestones which mainly contain a microfaunarepresented by Nummulites sp., Discocyclina sp, etc. The siliciclastic succession is represented by flysch deposits whichin the Makareshi structure are of Lower Oligocene age. The flysch unit consists of intercalations of sandstones and shales, together with the presence of slumps and conglomerates. Locally, Quaternary deposits mainly consisting of deposits of alluvial nature occur. Our study is focused only on the Upper Cretaceous carbonate succession. The studied area is located north-east of Borizana village $\left(41^{\circ} 32^{\prime} 3.76^{\prime \prime} \mathrm{N} ; 19^{\circ} 43^{\prime} 17.12^{\prime \prime} \mathrm{E}\right)$ and it is studied for the first time. The aim of this paper is to present a detailed analysis of shallow water environments and their interpretation based on microfacies analysis and their diagenetic features. 


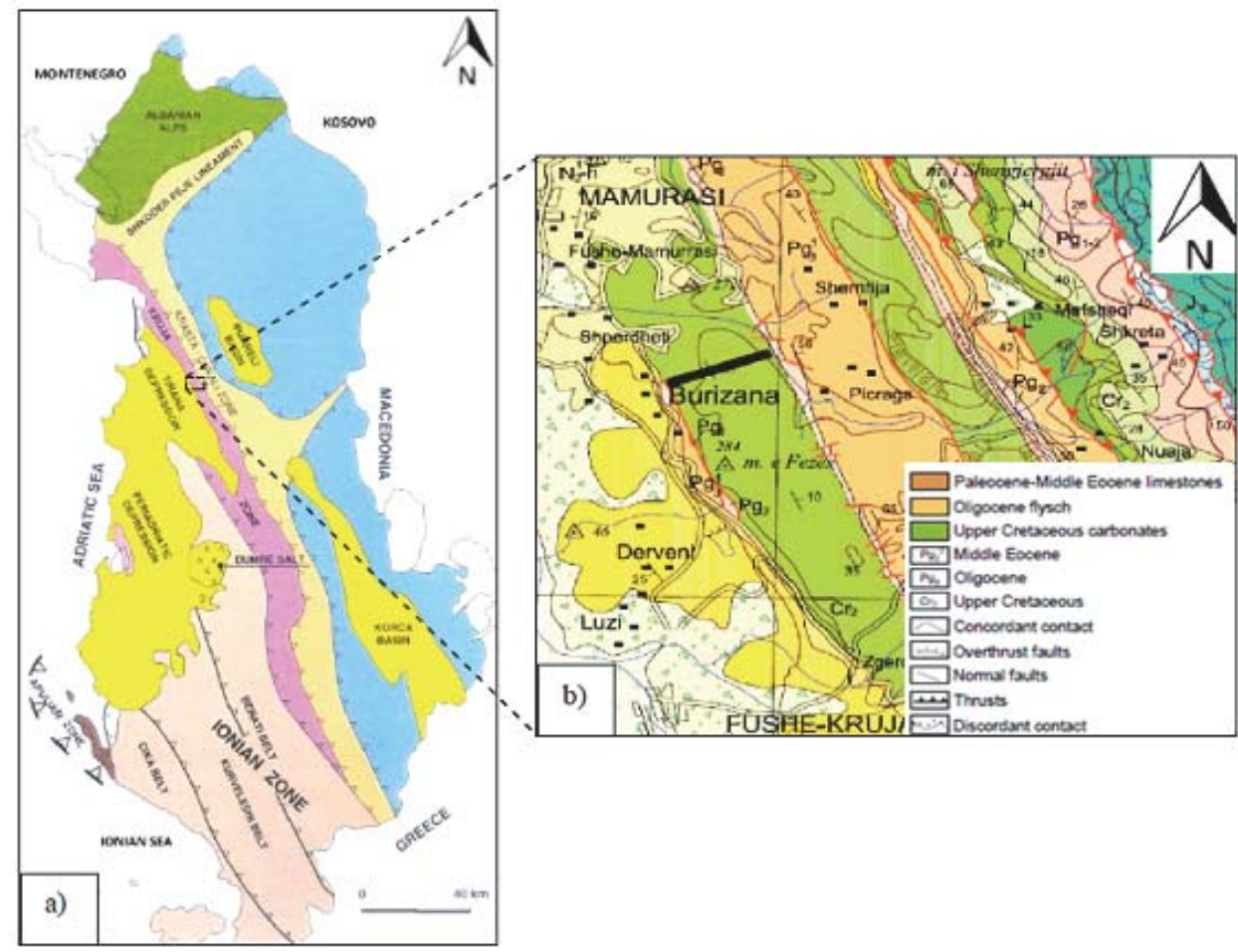

Figure 1a. Tectonic map of Albania. Dash lines indicate the location of Makareshi Structure. b- Geological map of the studied area (after I.N.G.F., 2002). The thick black line indicates the location of Borizana section.

\section{Materials and Methods}

During the field works, a systematic sampling together with detailed observations on the lithology, texture, rock color, bedding, sedimentary structures, diagenetic features, fossils and biogenic structures have been carried out. The scheme developed by Demicco and Hardie (1994) for shallow-marine carbonates has been taken into count. A total of 230 rock samples were collected for microfacies analysis and based on distinct lithological and textural variations, more than 250 thin sections were prepared and studied under polarized light microscope (Nikon Eclipse SQ/POL). The classification of carbonates following the nomenclature of Dunham (1962) and its modification by Embry and Klovan (1971) was used. Whereas for the determination of the depositional environments, the Standard Microfacies Types (SMF) and Facies zones classifications after Flugel (1972) and Wilson (1975) were used. The diagenetic study focuses on the diagenetic features that can be studied only in thin sections using standard optical petrography.

\section{Results}

\subsection{Microfacies}

The field observations and the petrographic analyses (i.e., the types of allochems, composition, texture, sedimentary structures and rock types) of thin sections allowed determining a number of six main microfacies associations which are described as follows:

\subsubsection{MFT- 1 Peloidal packstone/grainstone}

The peloidal packstone/grainstones, contain also different benthic foraminifera, mainly miliolids, Thaumatoporella parvovesiculifera, ostracods and various intraclasts (Plate 1, Fig. 1b), (Plate 1, Fig. 1a). The frequency of appearance of peloidal grainstone is relatively high in Borizana section and it was identified in different levels of it. The shape of peloidsvaries from rounded to sub-rounded, spherical, ellipsoidal to irregular, micro- and cryptocrystalline carbonate 
grains being generally smaller than other carbonate particles (Tucker and Wright, 1990; Flügel, 2004). The peloids are commonly devoid of internal structures and are either partly or completely micritized, sometimes are deformed and no lamination can be distinguished.

Paleoenvironmental interpretation: This microfacies is typical for the inner part of the inner platform environments with moderate water circulation and which belong to Facies Zone 8 (FZ8) standard microfacies type SMF

\subsubsection{MFT-2 Foraminiferal packstone/grainstone and foraminiferal grainstone}

The main characteristic of this microfacies is a moderate biodiversity. (Plate 1, Fig. 1c). The dominant benthic foraminifera are represented by cuneolinids, miliolids and textulariids (Plate 1, Fig. 1d). Bioeroded fragments of mollusks (mostly bivalves and gastropods) and peloids are also important contributors. The grains are poorly to medium sorted. Due to changes in the type of the allochems identified in some samples, a microfacies described as foraminiferal grainstone was identified.

Paleoenvironmental interpretation: These microfacies showing a high abundance of miliolids are very common in lagoonal environments (sometimes with elevated salinity) of restricted inner platforms (FZ8) or inner ramps (Flügel 2004). This microfacies is comparable to standard microfacies type SMF 18 Wilson (1975) and Flügel (2004), respectively.

\subsubsection{MFT- 3 Fenestrate wackstone/packsone}

This mirofacies contains (Plate 1, Fig. 1e), benthic foraminifera mainly represented by miliolids, Thaumatoporella parvovesiculifera, debris of mollusks and rare small peloids. The fenestral "bird's eye" cavities, are irregularly distributed (Plate 1, Fig. 1f) and sometimes filled with sparry cement. The largest ones form a dense network of irregularly shaped voids (stromatactoid fabric).

Paleoenvironmental interpretation: The fenestrate limestones have a polygenic origin such as wetting and drying of carbonates in upper intertidal/lower supratidal environments (Shinn 1968). Although fenestral limestones may form in different environments, their occurrence together with microbial bindstones and mud cracks constrain the interpretation to upper intertidal/lower supratidal environments (FZ8) (Flugel) and are attributed to standard microfacies type SMF21.

\subsubsection{MFT- 4 Microbial laminated bindstones}

This microfacies displays a fine planar and/or slightly wavy horizontal lamination (Plate 1, Fig. 1g, h) formed by the alternation of milimetric to centimetric laminae of wackestones, packstones and microbial laminae. Benthic foraminifera, microproblematica (Plate 2, Fig. 2i) and calcimicrobes (Decastronema kotori (DE CASTRO) (Plate 2, Fig. 2j) are the main biogenic components (Schlagintweit et al. 2015, in press). Thaumatoporella parvovesiculifera show varying in thickness of the wall whereby the thin-walled forms are often compacted and crushed. In addition, some laminae contain relatively common crustacean debris such as cuticles of crabs (Schlagintweit et al.2015, in press). Sparse dolomite crystals occasionally occur in some laminae.

Paleoenvironmental interpretation: This microfacies type corresponds to microbial mat that in generally form in a variety of marine (mostly supra and intertidal) and non-marine environments.

\subsubsection{MFT- 5 Rudist floatsone/rudstone}

This microfacies is described from beds up to several $\mathrm{cm}$ thick and consists of rudist-bearing rudstones (Plate 2, Fig. 2k) and floatstones (Plate 2, Fig. 2l) in a bioclastic wackestone/packstone matrix. The dominant biota is represented by rudists (mostly radiolitids) in association with rare Thaumatoporella parvovesiculifera and benthic foraminifera. Subsequently, micritic intraclasts and rare peloids were also described. The rudist-dominated assemblages occur in sheet-like concentrations in which individuals are loosely packed and completely lack mutual support. Typically for the rudist shells is lack the upper valve, theyare in growth position or, more commonly, slightly oblique (with random orientation of tests). The coarse sandy matrix consists of skeletal fragments, which derived from bioerosion and mechanical breakdown of rudist shells.

Paleoenvironmental interpretation: The relatively high fossil diversity and abundance is typical for normal-marine lagoonal environments with low to moderate water energy conditions. These environments corresponded to rudistinhabited zones, in which the main source of carbonate sediment was represented by the fragmentation of rudist shells 
(Spalluto, 2012).

\subsubsection{MFT -6 Dolomitic and dolomitized peloidal mudstone}

The dolomitic mudstone is generally homogeneous and unfossiliferous.and is a widespread in the upper levels of the studied section. This microfacies is unlaminated and characterized by the occurrence of planar-e (euhedral) fabrics of very fine with variation in dolomite crystal sizes (multimodal texture) (Plate 2, Fig. $2 \mathrm{~m}$ ). In some places, tiny black stringers (organic matter?) are observed. The dolomitized peloidal mudstone is made up of fine ovoidal peloids, probably related to microbial activity (Plate 2, Fig. 2n). The peloids are compacted, deformed with concavo-convex or tangential grain contacts.

Paleoenvironmental interpretation: The alternation of dolomitic limestones with levels of limestones and the presence of the idiotopic texture of dolomite crystals, testify probably of an early dolomitization that happened in a supratidal environment (sabkha). They correspond to the standard microfacies type SMF-23 and SMF-21 sensu Wilson (1975) and Flügel (2004).

\subsection{Diagenetic features}

The major diagenetic processes affecting carbonate sediments and rocks are micritization, dissolution,cementation, compaction, neomorphism, dolomitization, and the replacement of carbonate grains and matrix by non-carbonate minerals. Some of the aforementioned diagenetic features have been distinguished in the Borizana section, which include:

a. Compaction

Mechanical compaction: It displays different grains contact types (Taylor, 1950), from point contacts which indicate an initial compaction, concavo-convex up to tangential contact. Several biotas (e.g. Thaumatoporella parvovesiculifera and non-skeletal grains are deformed and compacted (Scholle, 2003) (Plate 2, Fig. 20-p). The presence of different types of fractures, veins and veinlets (Plate 3, Fig. 3q) are evidences of tectonic stresses and overburden pre and post cementation phases.

Chemical compaction: It has led to the formation of irregular anastomosing set of dissolution seams (Plate 3 , Fig. $3 \mathrm{r}$-s), thin but numerous, often with accumulations of insoluble residues.

b. Cementation:

Some of the features characterizing the cements are clear appearance, with well-defined contacts between crystals. Based on the morphology and the arrangement of crystals, different types of cement were differentiated under conventional light microscopy. The pore filling cements form calcite mosaics (Plate 3, Fig. 3t-u) (drusy, granular, and blocky, radiaxial, syntaxial cements) (Plate 3, Fig. 3v) as well as microcrystalline (micrite) cements, with drusy, equant and granular fabrics.

c. Neomorphism:

The term neomorphism (Folk, 1965) is based on a determination of the operative alteration processes as interpreted from the compositional and textural relationships between and successor minerals. It includes three processes: replacement, inversion and recrystallization.

Inversion: Aragonite shells were dissolved and replaced by calcite as its polymorph, the relicts of the original shells were preserved by the neomorphic calcite.

Recrystallization: An aggrading neomorphism took place in original micrite recrystallized in microsparite (Plate 4, Fig. 4w). It shows irregular crystals with variablesizes. . The boundaries between micritic and microsparitic zones are undulated and not well defined.

d. Dolomitization:

Dolomite is a diagenetic product that took place after deposition of the sediments. Arguments for this are preventing several partially dissolved or recrystallized foraminifera, ostracods and other bioclasts. These are sometimes overgrown by small dolomite crystals (Plate 4, Fig. 4x). Different types of crystals of dolomites were distinguished:

A first type displaying inequigranular, hypidiotopic fabrics, contact rhombs (loosely aggregated euhedral crystals in a fine grained matrix) with straight intercrystalline boundaries and some of crystal face junction preserved (Plate 4, Fig. 4y).

The second type consists in very fine dolomite crystals, inequigranular, porphyrotropic fabric, floating euhedral 
crystal rhombs in fine grained matrix (Plate 4, Fig. 4z).

\section{Discussions and Conclusions}

In the Upper Cretaceous studied section, almost all observed microfacies types (MFT), can be classified according to the Standard Microfacies Types (SMF-types) present in Facies Belts 8-9 (FZ 8 to FZ 9) sensu Wilson (1975), representing the inner-platform area (restricted lagoon and tidal flat).

Small-scale cycles, formed in a low-energy peritidal environment, are characterized by the repetitive stacking of the facies types. The cycles exhibit a shallowing upward trend (shallow subtidal to inter-supratidal).

Peritidal cycles are commonly dolomitized (completely or partially). A relationship between early dolomitization in a sabkha environment and eustatic sea-level oscillations is probable.

The field and laboratory analysis of the Upper Cretaceous succession from Borizana section indicate similarities and differences with other sections (La Route) from the Makareshi structure (Heba, 2008).

The characteristic Decastronema-Thaumatoporella association, commonly reported from Upper Cretaceous peritidal limestones of the Adriatic and Apenninic Carbonate Platforms, does occur in the Borizana section.

It is difficult to give an exact interpretation about the diagenetic setting only by petrographic observation but from the preliminary results achieved until now the diagenetic features derive from shallow burial diagenesis.

\section{References}

Demicco R.V. and Hardie L.A., (1994) Sedimentary Structures and Early Diagenetic Features of Shallow Marine Carbonates. Society of Sedimentary Geology, SEPM Atlas Series 1Tulsa, OK, 265

Dunham R.J., (1962) Classification of carbonate rocks according to depositional texture. In Ham, W.E. Classification of carbonate rocks. American Association of Petroleum Geologists Memoir. 1, 108-121

Embry AF. and Klovan JE., (1971) A Late Devonian reef tract on Northeastern Banks Island, NWT: Canadian Petroleum Geology Bulletin, 19, 730-781

Flügel E., (1972) Mikroproblematika in Dünnschliffen von Trias-Kalken. Mitteilungen der Gesellschaft der Geologie- und Bergbaustudenten Österreich 21, 957-988

Flügel E., (2004) Microfacies of carbonate rock: analysis interpretation and application. Springer, Berlin Heidelberg New York, 114, 272$333,700-720$

Folk R.L., (1965) Some aspects of recrystallization in ancient limestones. In: Dolomitization and limestone diagenesis (ed L.C. Pray and R.C. Murray). Soc. Econ. Paleon. Minerologists, spec. Publ., 13, 14-48

Heba G., (2008) Évolution de la plate-forme carbonatée de Kruja, en Albanie, du Crétacé à l'Eocène. Doctorat en ressources minérales à l'Université du Québec à Chicoutimi, Montreal, Canada, 28-56

Heba G., Prichonnet G., (2006) L'intervalle Crétacé terminal-Éocène de la marge passive d'Apulie en Albanie (Massifs de Kruje-Dajt et de Makareshi, Zone de Kruja): Faciès, organismes et cycles sédimentaires d'une plate-forme carbonatée. Bulletin de la Société Géologique de la France, 177, 5, 249-266

I.S.P.GJ. and I.GJ.N., (1983) La Géologie de l'Albanie. Monographie explicative de la Carte Géologique de l'Albanie au 1:200000. Éditions Naim Frasheri, Tirana, 1-300

Meço S., Aliaj S., (2000) Gelogy of Albania. Gebrüder Borntraeger. Berlin Stuttgart, 246

Papa A., (1970) Conceptions nouvelles sur la structure des Albanides. Présentation de la carte tectonique de l'Albanie au 1:200000. Bulletin de la Société Géologique de la France, 7, t. XII, 1096-1109

Peza L., (1973) Mise à jour d'un autre niveau stratigraphique dans la zone de Kruja (la coupe continue de "Shkalla e Vajes"). Permbledhje Studimesh, 4, 51-63

Peza L., (1975) Quelques données sur la structure géologique du massif de Makareshi. Permbledhje Studimesh 5, 33-44

Peza L., (1977) Une détermination plus approfondie de la stratigraphie du Sénonien supérieur dans la coupe continue de "Droja" et de "Shkalla e Vajes". Permbledhje Studimesh 3, 29-55

Peza L., (1982) Formacioni i "Shkëmbit te Vajes" dhe karakteristikat e tij. Permbledhje Studimesh, 1, 67-86

Robertson A., Shallo M., (2000) Mesozoic-Tertiary tectonic evolution of Albania in its regional Eastern Mediterranean context. Tectonophysics, 316, 197-254

Schlagintweit F., Kołodziej B., Qorri A., (2015) Foraminiferan-calcimicrobial benthic communities from Upper Cretaceous shallow-water carbonates of Albania (Kruja Zone). Cretaceous Research. Article in press

Scholle P. A. and Ulmer-Scholle D.S., (2003) A Color Guide to the Petrography of carbonate Rocks: AAPG Memoir 77, 330-370

Shinn E. A., (1968) Pratical signifiance of birdeyes structures in carbonate rocks. Journal of Sedimentary Petrology, 38, 215-223

Spalluto L., (2012) Facies evolution and sequence chronostratigraphy of a mid-Cretaceous shallow-water carbonate succession of the Apulia Carbonate Platform from the Northern Murge area (Apulia, southern Italy). Facies 58 (1), 17-36

Taylor J. M., (1950) Pore space reduction in sandstone: American Associtation of Petroleum Geologists Bulletin, V. 34, 701-716

Wilson J.L., (1975) Carbonate facies in geologic history. Springer Verlag, Berlin, 47, 460-471 


\section{Plate 1}

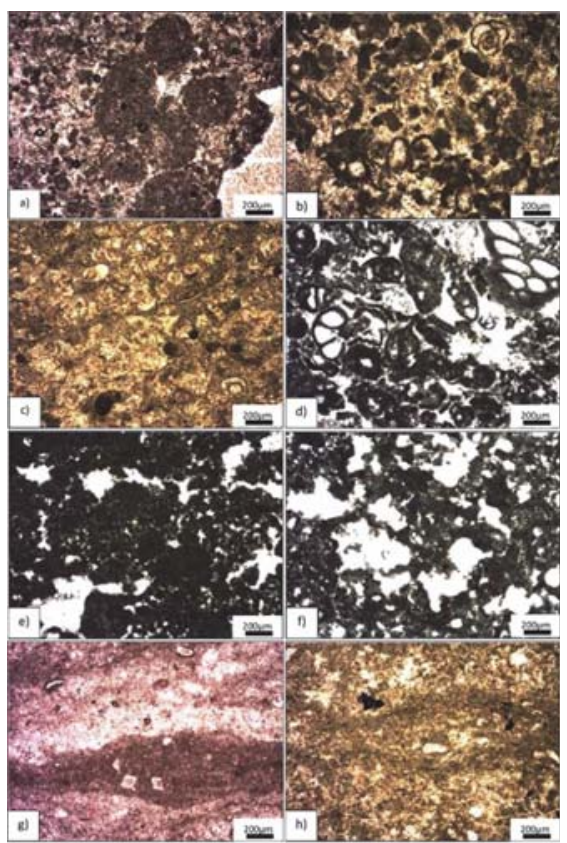

Fig. 1a Peloidal packstone to grainstone with peloids of different shapes and sizes, PPL.

Fig. 1b Peloidal in a packstone-grainstone with rare Thaumatoporella parvovesiculifera and benthic foraminifera (miliolidae, upper right), PPL.

Fig.1c Foraminiferal packstone/grainstone, PPL.

Fig. 1d Foraminiferal grainstone with different types of benthic foraminifera, PPL.

Fig. 1e Fenestrate peloidal packstone showing irregularly distributed voids filled with sparry calcite, PPL.

Fig. If Irregularly distributed empty fenestrae in a wackstone.

Fig. 1g Microbial layered bindstone. Note the presence of dolomite crystals and Decastronema kotori (DE CASTRO), PPL.

Fig. $1 \mathrm{~h}$ Slightly wavy microbial laminites, showing irregularly distributed spar filled fenestrae, PPL.

\section{Plate 2}

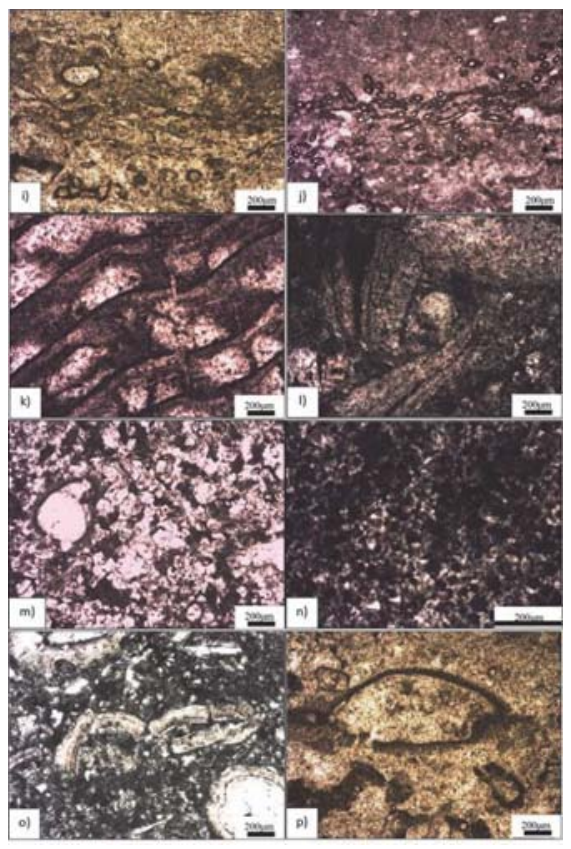


Fig. 2i Layered microbial bindstone, note the presence of Thaumatoporellaceans within this layers, PPL.

Fig. 2j Oriented Decastronema kotori (DE CASTRO), both in longitudinal and transverse sections.

Fig. $2 \mathrm{k}$ Skeletal rudstone with mm-large fragments of rudist.

Fig. 2l Floatstone entirely composed of individual disaggregated rudist shell fragments, PPL.

Fig. $2 m$ Dolomitized wackstone, PPL.

Fig. $2 n$ Tiny peloids with irregular shape, surrounded by micro-dolomite crystals, PPL.

Fig. 20-p Mechanical compaction resulting in fracturing of bivalve shells (Fig. 20) and Thaumatoporella parvovesiculifera fragments (Fig.2p).

Plate 3

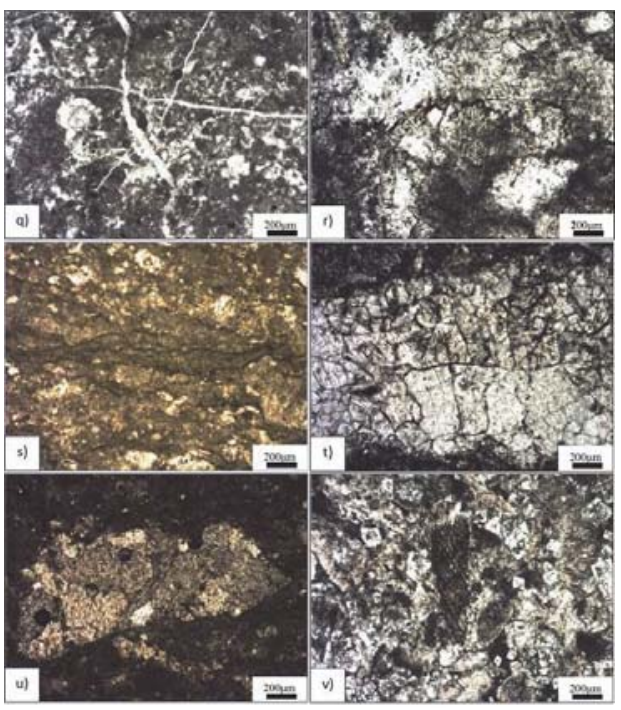

Fig. 3q Multiple generations of cross-cutting calcite veins and veinlets, PPL.

Fig. 3r Low-amplitude stylolites, PPL.

Fig. 3s Biomicrite with abundant and irregular thin solution seams.

Fig. 3t Blocky calcite characterized by various sizes of crystals, with hypidiotopic crystal fabric as pore filling cement, PPL.

Fig. 3u Void filled with blocky calcite cement consisting of medium to coarse grained crystals without a preferred orientation, XPL.

Fig. 3v Syntaxial calcite overgrowth cement formed probably on an echinoid fragment,PPL.

\section{Plate 4}

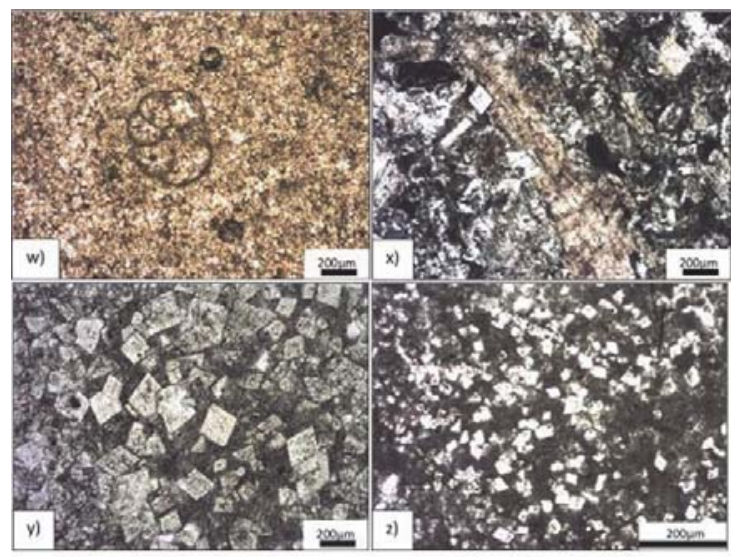

Fig. 4w Neomorphism of original micrite recrystallized in microsparite in a wackstone, PPL.

Fig. 4x Planar -e (Euhedral) dolomite crystals in a dolomitized wackstone, PPL

Fig. 4y Planar-e (Euhedral) dolomite crystalswith visible crystals face junctions, PPL.

Fig. $4 z$ Planar-e (Euhedral) dolomite crystals, some of them exhibit cloudy centers and straight boundaries, PPL. 
